\title{
LITOMOSOIDES YUTAJENSIS N. SP., FIRST RECORD OF THIS FILARIAL GENUS IN A MORMOOPID BAT
}

\author{
GUERRERO R.", MARTIN C.**,**** \& BAIN O.**
}

\section{Summary:}

Twenty-five bats were trapped in Yutaje (Amazonas, Venezuela) and examined for Litomosoides (Filarioidea: Onchocercidae). Of the nine recovered bat species, only Pteronotus parnelli was infected; it is a cave-dwelling species belonging to a family, Mormoopidae, which has not previously been included in the host range of the genus. The new species, L. yutajensis n. sp., has two median cephalic bosses covered with rugosities and differs from the 15 recognized species and subspecies from bats in several characters. Alike L. molossi Esslinger, 1973, L. chandleri Esslinger, 1973 and L. chitwoodi Bain, Guerrero, Rodriguez 2003, the new species has cuticular lateral bosses on the body. Eight of $10 \mathrm{P}$. parnelli were microfilaraemic, but only three had adult worms, showing that microfilariae survive longer than adults, which could lengthen the period of transmission. No infective larvae were detected in the following macronyssid mites: 58 Ornithonyssus bacoti, Ornithonyssinae, experimentally fed on microfilaraemic bats and dissected 15 days later, and a few Radfordiella sp., Macronyssinae, recovered from P. parnelli.

KEY WORDS : filariae, Onchocercidae, Litomosoides, new species, Chiroptera, biology, mites, Macronyssidae.

\section{INTRODUCTION}

1 The filarial genus Litomosoides has several interesting features. It has been presented as an example of evolution by capture between bats, rodents and marsupials (Bain et al., 1980; Brant \& Gardner, 2000; Guerrero et al., 2002). One of its species, L. sigmodontis Chandler, 1931, has become a much-used murine model for immunological analyses of filariases (Bain \& Philipp, 1991; Martin et al., 2001; Bain, 2002). Moreover, like several filariae of humans

\footnotetext{
" Instituto de Zoologia Tropical, Faculdad de Ciencias, Universidad Central de Venezuela, PO Box 47058, 1041A Caracas, Venezuela. ** Parasitologie comparée et Modèles expérimentaux, UMR 0307 associée à l'INSERM (U567), Muséum National d'Histoire Naturelle et École Pratique des Hautes Études, 61, rue Buffon, 75231 Paris Cedex 05, France.

*** Leukocyte Biology Section, Division of Biomedical Sciences, Faculty of Mecicine, Imperial College of Science, Technology and Medicine, London, United Kingdom.

Correspondence: O. Bain. E-mail: bain@mnhn.fr
}

Résumé : LITOMOSOIDES YUTAIENSIS N. SP., PREMIÈRE FILAIRE DU GENRF RAPPORTÉE CHEZ UNE CHAUVE-SOURIS MORMOOPIDAE

Vingt-cinq chauves-souris ont été capturées à Yutaje (Amazonas, Venezuela) pour rechercher des Litomosoides (Filarioidea Onchocercidae). Sur les neuf espèces de chiroptères récoltées, seul Pteronotus parnelli était parasité ; c'est une espèce cavernicole de la famille des Mormoopidae, jusqu'à présent non répertoriée dans le spectre d'hôtes de Litomosoides. L. yutajensis n. sp. a deux mammelons céphaliques médians couverts d'aspérités et diffère des 15 espèces et sous-espèces connues chez les chauves-souris par plusieurs autres caractères. Comme L. molossi Esslinger, 1973, L. chandleri Esslinger, 1973, et L. chitwoodi Bain, Guerrero, Rodriguez 2003, la nouvelle espèce a des perles cuticulaires latérales sur le corps. Sept des 10 $P$. parnelli capturés avaient des microfilaires sanguines et, parmi ceux-ci, trois n'avaient plus de filaires adultes montrant que les microfilaires pourraient ainsi allonger la période de transmission. Aucune larve infectante n'a été récoltée chez les Macronyssidae disséqués: 58 Bdellonyssus bacoti, Ornithonyssinae, gorgés expérimentalement sur chauves-souris microfilariennes, et analysés 15 jours plus tard, et quelques Radfordiella sp., Macronyssinae, récoltés sur ces chauves-souris.

MOTS CLÉS : filaires, Onchocercidae, Litomosoides, nouvelle espèce, Chiroptera, biologie, acariens, Macronyssidae.

(Bandi et al., 1999), this species harbours the endosymbiotic bacterium Wolbachia, which might revolutionize the concept of filarial pathologies and their therapy (Gencchi et al., 1998; Hoerauf \& Brattig, 2002; Saint Andre et al., 2002). The phylogeny of Wolbachia contributes to the understanding of the evolution of onchocercid filariae (Bandi et al., 2001; Casiraghi et al., 2001).

Here we describe a new species of Litomosoides parasitic in Mormoopidae, a family of bats which has not previously been included in the host range of the genus. Some aspects of its biology are reported, and its relationships with other members of Litomosoides are considered.

\section{MATERIALS AND METHODS} The study area was Yutaje ( $5^{\circ} 36^{\prime} 30^{\prime \prime} \mathrm{N}, 66^{\circ} 06$ $51^{\prime \prime}(\mathrm{W})$, Amazonas State, Venezuela. It is undisturbed tropical rain forest. 
Two mist nets were placed at ground level and opened in the evening just before dusk, for three hours. Trapped bats were placed individually in cotton bags. A blood sample of about $2 \mu \mathrm{l}$ was taken by clipping a toenail; each blood sample was immediately examined microscopically for living microfilariae. When microfilariae were present, specimens of the macronyssid mite Ornithonyssus bacoti (Hirst 1913) were fed on the infected bat. Mites from a laboratory colony were kept in small tubes, $6 \mathrm{~cm} / 1.5 \mathrm{~cm}$, each containing 25 mites (Diagne et al., 1990). For feeding, the mites were released on to a bat which had been gently immobilized in soft wire mesh and placed overnight above a container filled with water. In the morning the fed mites were recovered from the water and replaced in the tubes, as described by Bain et al. (2002). No incubator was available and the tubes were kept in a plastic box with moist cotton wool, at a temperature varying from 23 to $28^{\circ} \mathrm{C}$; the box was opened daily for a few minutes to allow air to enter.

All bats were identified following the classification of Simons (1998). Any natural ectoparasites were recovered and a few mites were kept alive in tubes (as described for $O$. bacoti) for subsequent examination for filarial larvae.

When the bats were killed, thick blood films were prepared, and any adult filariae as well as nematodes from the digestive tract were recovered and fixed in hot $70 \%$ alcohol. The morphological characters of the filariae were studied as described by Guerrero et al. (2002) and illustrations were prepared using a drawing tube. To stain the nuclei of microfilariae extracted from the uteri of fixed females, the vital stain Meldolan Blue was added to the aqueous medium; staining lasted for a few hours; the microfilarial sheath was also visualized with this technique.

\section{RESULTS}

MORPHOLOGICAL STUDY OF THE FILARIAE FROM THE MORMOOPID PTERONOTUS PARNELLI (GRAY 1843)

$\mathrm{F}$ ilarial worms were located in the peritoneal cavity of $P$. parnelli, close to the dorsal wall, often under the liver. The studied material comprises the four males and five females recovered from the type host, specimen $102 \mathrm{CV}$, and a male worm, a posterior male extremity and a female obtained from bat $105 \mathrm{CV}$, and one of three males found in bat $117 \mathrm{CV}$, the other two having been fixed to examine for $\mathrm{Wol}$ bachia. Measurements are presented in Tables I and II and the morphology is illustrated in figures 1 and 2 .

Head attenuated with two median bosses, both irregularly covered with tiny rugosities; in addition, two median cuticular groves often present. Four small externo-labial papillae arranged in a rectangle stretched dorso-ventrally, and two larger ventral cephalic papillae posterior to amphids. Buccal capsule of similar size in both sexes, posteriorly embedded in the oesophagus, slightly longer than broad (height/width ratio 1 to 1.6), with a thickened ring at its mid-length, more pronounced in females, giving the capsule a bell-like shape; frequent irregularities of the internal structure of the posterior wall (Fig. 2F); buccal cavity irregular in diameter, with one or two transverse grooves and often wider in the posterior third. Oesophagus with no distinct glandular part.

Male with three-four pairs of caudal papillae, the third pair being almost aligned and the last pair often reduced to one papilla. Spicules delicate; left spicule with handle, long proximal part of lamina devoid of longitudinally folded membranous alae, and thread-like distal part which, after dissection, appeared to be

\begin{tabular}{|c|c|c|c|c|c|}
\hline Sample & $102 \mathrm{CV}$ & $102 \mathrm{CV}$ & $102 \mathrm{CV}$ & $102 \mathrm{CV}$ & $105 \mathrm{CV}$ \\
\hline Measurements & Holotype & Paratype & Paratype & Paratype & \\
\hline Length (mm) & 17.00 & 17.75 & 15.50 & 17.15 & 16.95 \\
\hline Width max. & 123 & 120 & 108 & 102 & 83 \\
\hline at nerve ring & 50 & 50 & 52 & 50 & 52 \\
\hline at oe-in. junction & 70 & 78 & 70 & 65 & 65 \\
\hline Buccal capsule $\mathrm{H} \times \mathrm{W}$ & $13.2 \times 11.4$ & $16 \times 10$ & $11.5 \times 11.5$ & $14 \times 12$ & $16 \times 10$ \\
\hline Oesophagus $\mathrm{L} \times \mathrm{W}$ & $619 \times 22$ & $637 \times 25$ & $569 \times 19$ & $581 \times 21$ & $546 \times 23$ \\
\hline Nerve ring & 266 & 245 & 213 & 220 & 289 \\
\hline Tail $\mathrm{L} \times \mathrm{W}$ & $150 \times 40$ & $160 \times 39$ & $145 \times 33$ & $154 \times 34$ & $126 \times 37$ \\
\hline Left spicule & 257 & 279 & 303 & no & 288 \\
\hline handle & 180 & 182 & 206 & no & 195 \\
\hline Right spicule & 58 & $>53$ & 68 & no & 64 \\
\hline Area rugosa from cloaca & 158 & 218 & 187 & 122 & 195 \\
\hline length & 1,483 & 1,885 & 1,520 & 1,870 & 1,680 \\
\hline ridge height & $1.0-1.5$ & & $1.0-2.1$ & $1.0-1.6$ & $0.7-1.5$ \\
\hline ridges distance & $4-7$ & & $7-8$ & $6-7$ & 6-9 \\
\hline
\end{tabular}

Table I. - Measurements of males of Litomosoides yutajensis $\mathrm{n} . \mathrm{sp}$ 


\begin{tabular}{|c|c|c|c|c|c|c|}
\hline Sample & $102 \mathrm{CV}$ & $102 \mathrm{CV}$ & $102 \mathrm{CV}$ & $102 \mathrm{CV}$ & $102 \mathrm{CV}$ & $105 \mathrm{CV}$ \\
\hline Measurements & Allotype & Paratype & Paratype & Paratype & Paratype & \\
\hline Length (mm) & 45.80 & 43.30 & 44.75 & 36.45 & $?$ & 37.50 \\
\hline Width max. & 195 & 202 & 195 & 202 & 202 & 205 \\
\hline at nerve ring & 72 & 69 & 68 & 65 & 69 & 72 \\
\hline at oe-int. junction & 120 & 110 & 118 & 126 & 160 & 150 \\
\hline Buccal capsule $\mathrm{H} \times \mathrm{W}$ & $15 \times 13$ & $14.4 \times 14.3$ & $15.8 \times 11.5$ & $15.5 \times 13$ & $16 \times 13$ & $15.8 \times 11.5$ \\
\hline Oesophagus $\mathrm{L} \times \mathrm{W}$ & $800 \times 22$ & $672 \times 25$ & $712 \times 29$ & $757 \times 23$ & $1,090 \times 29$ & $950 \times 22$ \\
\hline Nerve ring & 257 & 260 & 246 & 242 & 307 & 296 \\
\hline Tail $\mathrm{L} \times \mathrm{W}$ & $290 \times 58$ & $314 \times 65$ & $336 \times 63$ & $285 \times 67$ & $219 \times 54$ & $275 \times 61$ \\
\hline Vulva & 500 & 513 & 480 & 535 & 450 & 565 \\
\hline Vagina $L \times W$ & $90 \times 75$ & $76 \times 56$ & $94 \times 72$ & $84 \times 76$ & $116 \times 72$ & $98 \times 67$ \\
\hline
\end{tabular}

Table II. - Measurements of females of Litomosoides yutajensis n. sp.
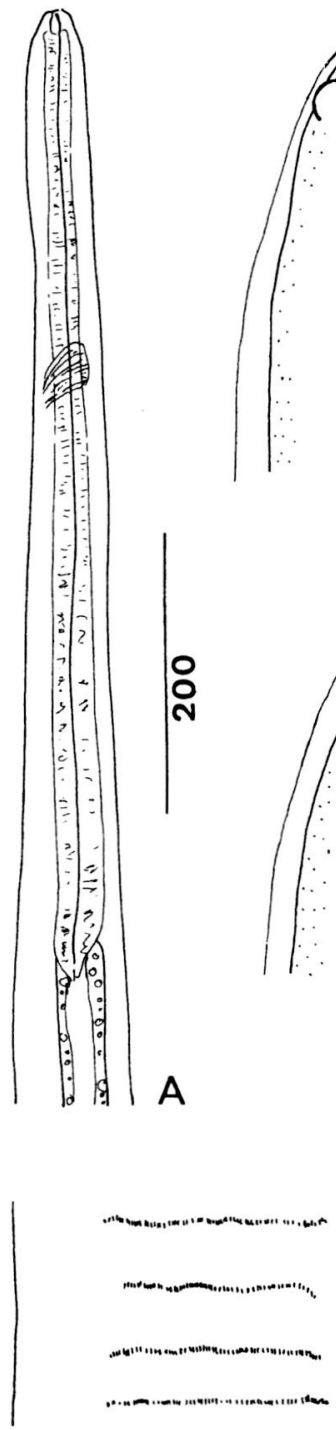

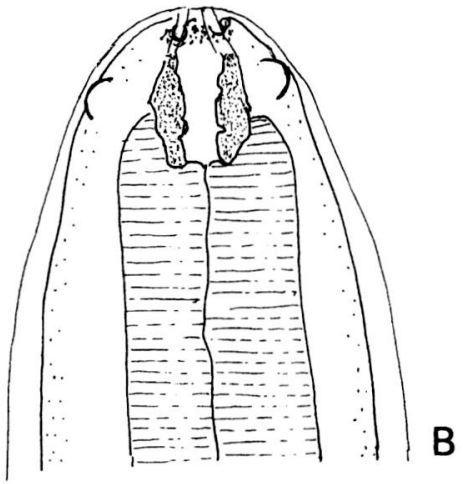

B

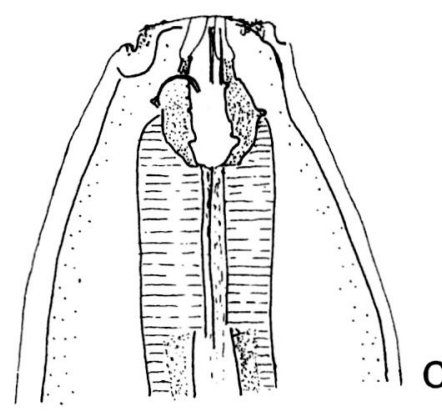

C
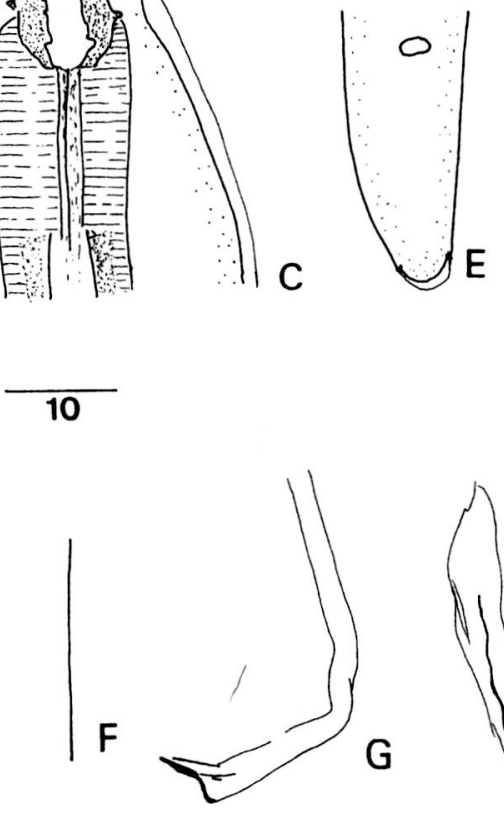
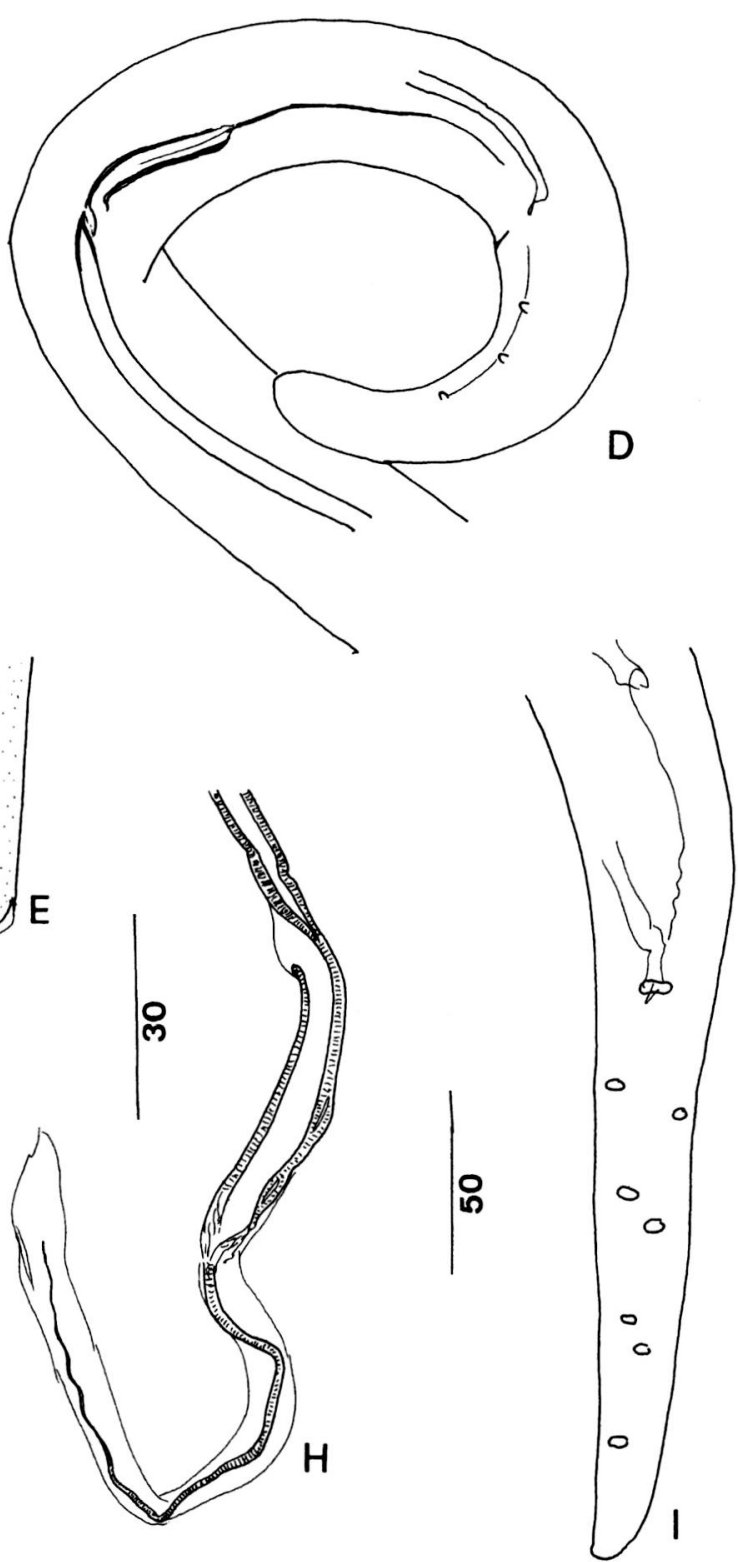

Fig. 1. - Litomosoides yutajensis n. sp. Male. A. Anterior region, left lateral view (holotype). B, C. Head, ventral and left lateral views, respectively (holotype). D. Posterior region, left lateral view. E. Tail extremity, ventral view. F. Area rugosa at mid-length, ventral view. G. Right spicule, lateral view, right lateral view. H. Lamina of left spicule (dissected out from spicular sheath). I. Tail, ventral view. Scales in $\mu$ m: A, 200; B, C, 10; D, I, 50; E, F, G, H, 30. 

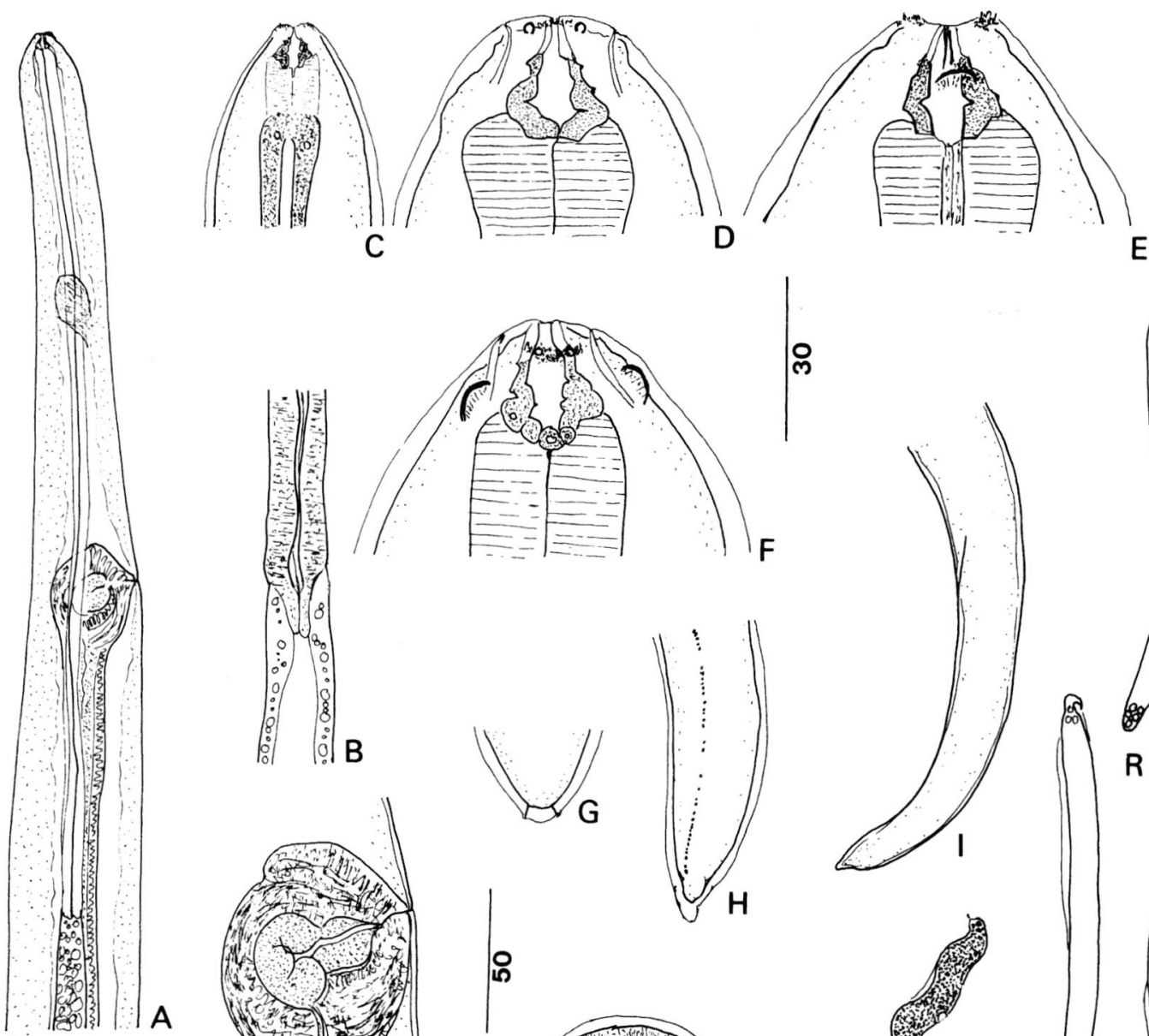

E

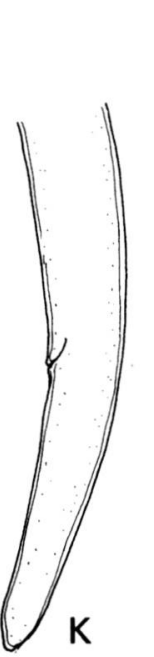

\section{A}
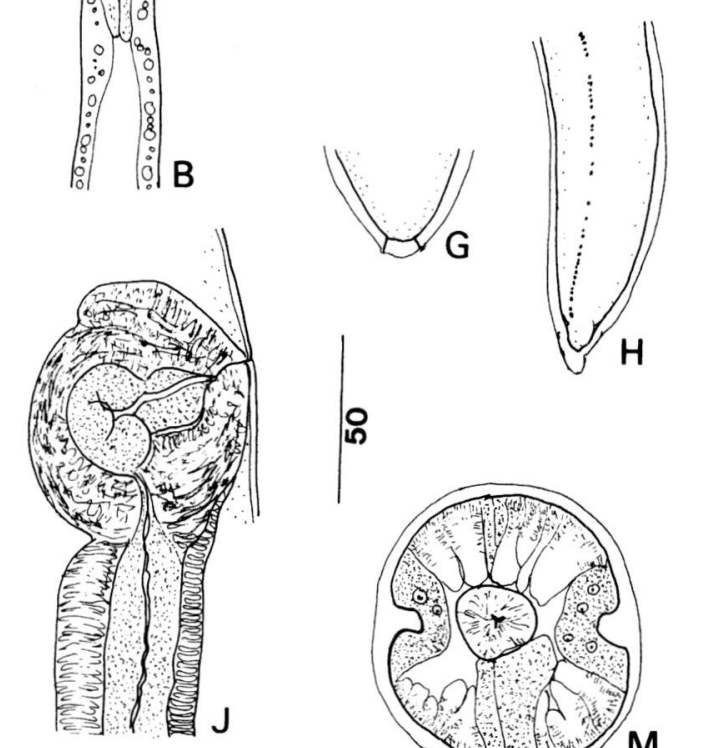

.
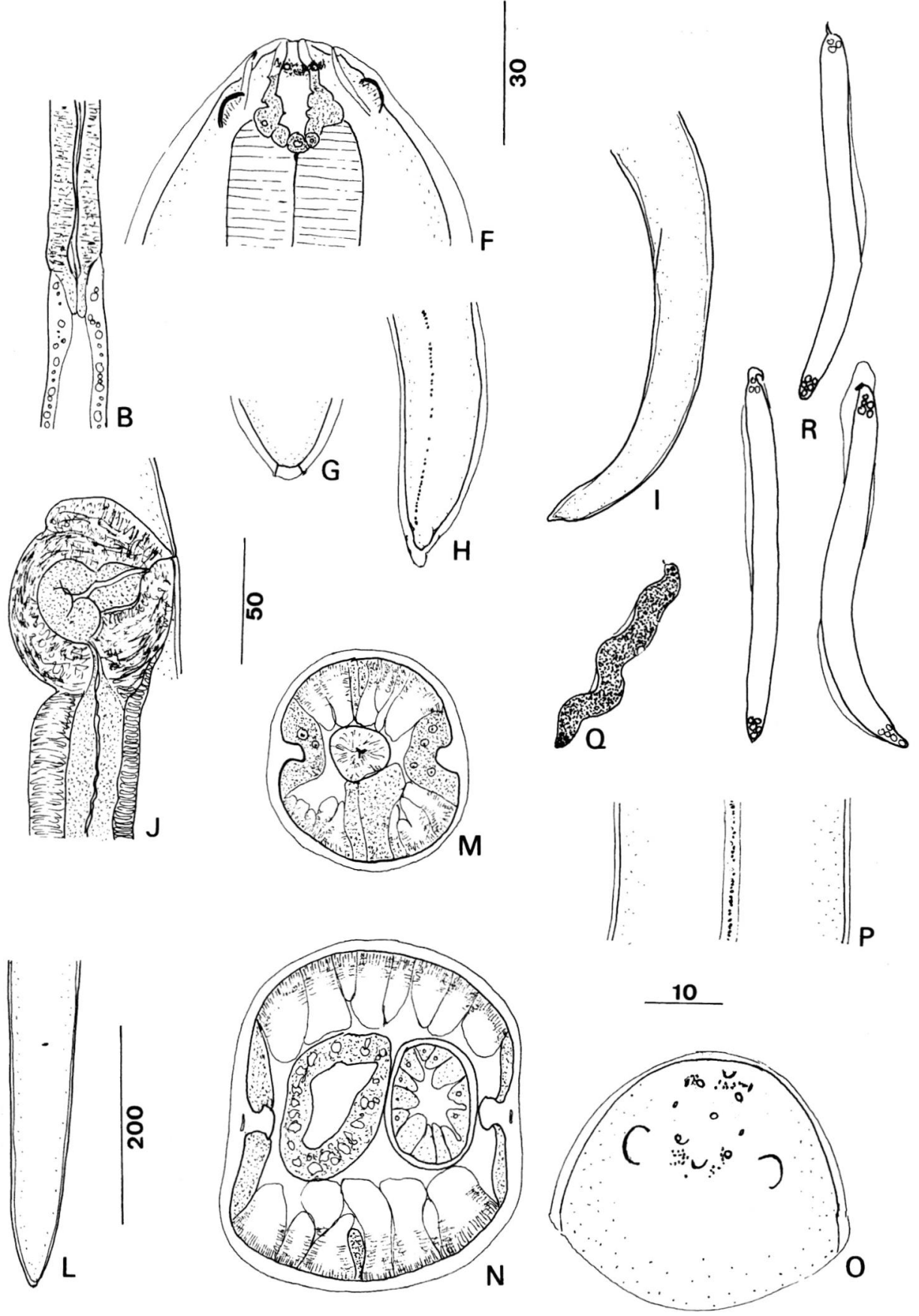

Fig. 2. - Litomosoides yutajensis n. sp. Female. A. Anterior region, right lateral view (allotype). B. Oesophageal-intestinal junction. C. Anterior extremity, lateral view (allotype). D. Head, dorsal view (allotype). E, F. Head, right lateral and ventral views, respectively (paratype). G. Caudal extremity, ventral view. H. Caudal ornamentation of tail, left lateral view. I. Tail, lateral view (allotype). J. Vagina, right lateral view. K, L. Tail of a paratype, left lateral and ventral view, respectively. M. Cross section at level of oesophagus. N. Cross section, posterior to vagina. O. Head, semi-apical view. P. Lateral cuticular ornamentation, $700 \mu \mathrm{m}$ from tail. Q. Microfilaria from a thick blood smear (type host). R. Three microfilariae extracted from uteri (paratype). Scales in $\mu$ m: A, I, K, L, 200; B, C, G, Q, 30; D, E, F, O, R, 10; H, J, M, N, P, 50. 
composed of a cuticular axis with lateral alae, followed by a terminal membranous flap (one male was devoid of a left spicule). Right spicule uniformly cuticularized and with prominent subterminal dorsal heel. Area rugosa present. No bosses on the lateral line of the body cuticle.

Female with vulva at level of middle of the oesophagus, spherical vagina; tail straight or slightly bent ventrally, with conical extremity; a tiny tubercle near each phasmid. In the posterior mid-part of the body, cuticle ornamented with a lateral row of bosses. Mushroom-shaped internal lateral thickenings of the body cuticle, near level of oesophageal-intestinal junction.

Microfilaria. From ovijector $(n=6), 57.5 \mu \mathrm{m}$ long (extremes 55-60 $\mu \mathrm{m}$ ) and $3.7 \mu \mathrm{m}$ wide $(3.6-4 \mu \mathrm{m})$; body attenuated at both extremities; salient cephalic hook, posterior extremity conical, thick and nucleated; sheath of same length as the body of the microfilaria. In Giemsa-stained blood films, the microfilariae were shorter $(43-48 \mu \mathrm{m})$ and thicker $(6 \mu \mathrm{m})$ and a cephalic hook and sheath were often identified.

\section{Taxonomic summary}

Type host: Pteronotus parnelli (Gray, 1843) Mormoopidae, Noctilionoidea, Chiroptera.

Infection site: Peritoneal cavity.

Type locality/collection dates: Yutaje, Amazonas, Venezuela, 4-8/12/2002 except no. 433 SE collected in January 2000.

Specimens deposited: Holo- and alloptypes $102 \mathrm{CV}$ are in the collection of the Departamento de Parasitologia, Museo de Biologia, Universitas Central de Venezuela (CP-MBUC $n^{\circ}$ 4-401201). Other specimens are deposited in the collections of the Muséum National d'Histoire Naturelle, Paris: paratypes $102 \mathrm{CV}$, other specimens $105 \mathrm{CV}$ and $117 \mathrm{CV}$; slides of blood microfilariae $100 \mathrm{CV}, 112 \mathrm{CV}, 113 \mathrm{CV}, 126 \mathrm{CV}, 127 \mathrm{CV}$ and $433 \mathrm{SE}$.

\section{BIOLOGICAL DATA}

In Yutaje, the bat species most frequently captured in December 2001 was P. parnelli, a species living in caves: 10 specimens in a total of 25 bats. The 15 other bats were Carollia perspicillata (Linnaeus, 1758) $(n=4)$, C. castanea H. Allen, 1890 and C. brevicauda (Schinz, 1821) (one specimen each), Phyllostomus hastatus (Pallas, 1767) $(\mathrm{n}=3)$ and P. elongatus (Geoffroy St. Hilaire, 1810) $(\mathrm{n}=1)$, Artibeus obscurus Schinz, 1821 $(\mathrm{n}=3)$, Tonatia saurophila Koopman \& Williams, $1951(\mathrm{n}=1)$ and Vampyrum spectrum (Linnaeus, 1758) $(\mathrm{n}=1)$. None were infected with filariae.

Eight of $10 \mathrm{P}$. parnelli were infected; two had adult worms of both sexes and blood microfilariae, one harboured three males and had no blood microfilariae, five had only blood microfilariae. O. bacoti, Ornithonyssinae, was fed on three microfilarial bats. Only 58 of 408 fed mites survived 15 days and, at dissection, none harboured infective larvae or any other developing larvae. The few wild mites recovered from $P$. parnelli were a different macronyssid, a new species of Radfordiella Fonseca, 1948 (to be described by R. Guerrero), Macronyssinae; no filarial larva was recovered at dissection.

\section{DISCUSSION}

1 The generic identification of the new material to Litomosoides is based upon the large thick buccal capsule which is posteriorly embedded in the oesophagus, and the sheathed microfilaria with a salient cephalic hook and body attenuated at both extremities (Guerrero et al., 2002). The right spicule of these specimens is delicate but it is sclerotized right up to its distal extremity and the left spicule has a distal flap, showing that they belong to the L. carinii group. This group is represented in marsupials, rodents and bats from the New World (Bain et al., 1989). In Chiroptera, however, several species were assigned to this group or to the L. sigmodontis group only based on the original descriptions and, as shown by Bain et al. (2003) for L. hamletti Sandground, 1934, these descriptions may be contradicted when the type materials are re-examined. Consequently the material from $P$. parnelli will be compared with all known species from bats.

No species of Litomosoides hitherto studied in detail has the median cephalic bosses with rugosities seen in our specimens, and all are distinct in several other characters:

The two species from marsupials (Guerrero et al., 2002), L. petteri Bain, Petit, Berteaux, 1980 and L. wilsoni Guerrero, Martin, Gardner \& Bain, 2002, have a tubular buccal cavity, caudal papillae in the male symmetrically arranged, a right spicule with a salient terminal cap or hook, and microfilariae with attenuated posterior extremities. In addition, $L$. petteri has eight head papillae symmetrically arranged, a longer buccal capsule, a glandular region of the oesophagus, and longer microfilariae, while L. wilsoni has a shorter oesophagus, a longer right spicule, and a post-oesophageal vulva.

The five species from rodents (Notarnicola \& Navone, 2002) L. carinii (Travassos, 1919), redescribed by Bain et al. (1989), L. silvai Padhila \& de Faria, 1977, redescribed by Moraes Neto et al. (1996) and Notarnicola et al. (2000), L. scotti Forrester \& Kinsella, 1977, redescribed by Bain et al. (1989), L. bonaerensis Notarnicola, Bain \& Navone, 2000, and L. odilae Notarnicola \& Navone, 2002 have a post-oesophageal vulva, a longer right spicule (about $100 \mu \mathrm{m}$ long) with a ter- 
minal dorsal hook; each species also differs in the shape of the buccal capsule and, except for L. carinii, in its length (shorter for $L$. scotti, longer for the three other species). The microfilariae of $L$. carinii have not been described; those of the other species have an attenuated posterior extremity.

The 15 Litomosoides species and subspecies currently known from bats (Notarnicola et al., 2000; Guerrero et al., 2002, Bain et al., 2003) are distinct from our material. Two are known only as microfilariae: those of L. colombiensis Esslinger, 1973 are twice as long and taper posteriorly to form a narrow tail; while those of L. caliensis Esslinger, 1973 have a thinner posterior extremity with two aligned caudal nuclei. L. teshi Esslinger, 1973, is larger, has a long thin tail in both sexes and is presently the only species which undoubtedly belongs to the sigmodontis group. The dimensions of L. brasiliensis Lins de Almeida, 1936 and L. serpiculae Guerrero, Martin, Gardner \& Bain, 2002 are much larger and the shape of the spicules is different. The six following species: L. leonilavasquezae Caballero, 1939 (see also Caballero, 1944), and L. fosteri Caballero, 1947 (both placed by Bain et al., 1989 in the sigmodontis group), L. artibei Esslinger, 1973 and L. solari Guerrero, Martin, Gardner \& Bain, 2002, both known by the female and its microfilariae, $L . h$. hamletti Sandground, 1934 and $L$. h. penai Jiménez-Quirós \& Arroyo, 1960, both redescribed by Bain et al. (2003) are similar in length to our specimens but have a narrow cylindrical buccal cavity; in addition the three first species have a post-oesophageal vulva; the two last species have a right spicule with a terminal hook. L. molossi Esslinger, 1973, L. chitwoodi Bain, Guerrero \& Rodriguez, 2003 (= Litomosoides sp. Chitwood, 1938), known as the female only and re-examined by Esslinger (1973), and L. chandleri Esslinger, 1973 have a lateral line of cuticular bosses in the female as do our specimens; however L. molossi is much smaller with a post-oesophageal vulva, a narrow tubular buccal cavity, a shorter left spicule with a relatively longer handle, two caudal lappets in the female, and longer microfilariae with attenuated posterior extremities; $L$. chitwoodi is shorter, with a post-oesophageal vulva and a very long tail (almost $600 \mu \mathrm{m}$ ); L. chandleri has a shorter body in both sexes, a less anterior vulva, a shorter tail in the male with only one or two pairs of caudal papillae, a right spicule with a distal cap, and microfilariae with more attenuated posterior extremities (Esslinger, 1973; Guerrero et al., 2002). Finally, L. guiterasi (Pérez Vigueras, 1934), which resembles L. chandleri (cf. Bain et al., 2003), differs from our specimens in that the body is twice as short, the vulva is near the distal extremity of the oesophagus and in the male, the tail and the left spicule are shorter. The present material is thus a new species, that we name Litomosoides yutajensis n. sp.

\section{CONCLUSION}

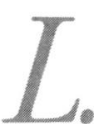

yutajensis n. sp. from Mormoopidae has no phylogenetically important characters which diffe1. rentiate it from the species found in other Chiroptera. These species are mostly parasitic in another family of Noctilionoidea, the Phyllostomidae, with a few exceptions such as L. molossi from Molossidae (Vespertilionoidea) or L. brasiliensis from Phyllostomidae and Vespertilionidae (Vespertilionoidea) ( $c f$. Lins de Almeida, 1936; Diaz-Ungria, 1963).

Filarial infection of $P$. parnelli was often revealed only by the presence of microfilariae. The persistence of this blood stage when adult worms have already been destroyed and eliminated is often questionable, but in these cases and that published concerning L. chandleri (Bain et al., 2002) it is certain, because bats are small animals in which coelomic filariae cannot be overlooked. It is interesting to relate these observations to those made with filarial models, in which it was shown that the first larval stage, the microfilaria, seems to be controlled by different immunological mechanisms from the adult stage (Lawrence, 1996)

Attempts to obtain infective larvae of L. yutajensis from mites did not succeed with the two macronyssid species examined. Radfordiella sp. recovered from $P$. parnelli did not survive long enough to assess their vector capacity for L. yutajensis and, contrary to previous work with another species from a bat (Bain et al., 2002), no larvae were obtained from $O$. bacoti. This could be due to the insufficiently high density of the microfilariae in blood, the instability of the temperature during postfeeding maintenance of mites, and/or the poor survival rate of the mites; alternatively, it might indicate that O. bacoti does not permit development of L. yutajensis. O. bacoti has not been collected from P. parnelli nor from any other South American bat (Saunders, 1975), whereas it was common on the terrestrial mammals which may harbour Litomosoides species.

\section{ACKNOWLEDGEMENTS}

This study was partially financed by the Consejo Nacional de Investigaciones Cientificas y Tecnologicas and the Centre National de la Recherche Scientifique (CNRS), project PI-99000230. We thank heartily Dr J.R. Baker who very patiently revised the English version.

\section{REFERENCES}

BAIN O. Evolutionary relationships among filarial nematodes In : World Class Parasites, 5, The Filaria, edited by Klei T.R. \& Rajan T.V., Kluwer Academic Publishers, series Editors Black S.J. \& Seed J.R., 2002, 21-30. 
Bain O. \& PhiLIPp M. Modèles animaux utiles pour l'étude des phénomènes parasitaires : filaires et autres parasites. Annales de Parasitologie Humaine et Comparée, 1991, 66, (suppl. 1), 64-68.

Bain O., Petit G. \& Berteaux S. Description de deux nouvelles filaires du genre Litomosoides et de leurs stades infestants. Annales de Parasitologie Humaine et Comparée, 1980, 55, 225-237.

Bain O., Petit G. \& Diagne M. Étude de quelques Litomosoides parasites de rongeurs; conséquences taxonomiques. Annales de Parasitologie Humaine et Comparée, 1989, 64 , 268-289.

Bain O., Babayan S., Gomes J. \& Guerrero R. First account on the larval biology of a Litomosoides filaria, from a bat. Parassitologia, 2002, 44, 89-92.

Bain O., Guerrero R., Rodrigues-Ortiz B., Babayan S. \& JouVENET N. Examination of type material of two species of Litomosoides (Filarioidea: Onchocercidae), parasites from bats; taxonomic consequences. Parasite, 2003, 10, 211-218.

Bandi C., Slatko B. \& O'Neill S. L. Wolbachia genomes and the many faces of symbiosis. Parasitology Today, 1999, 15, 428-429.

Bandi C., Anderson T.J.C., Gencchi C. \& Blaxter M. The Wolbachia endosymbionts of filarial nematodes. Parts $1 \& 2$, pp. 25-43. In: Parasitic nematodes: molecular biology, biochemistry and immunology. Kennedy M.W. and Harnett W., eds., CABI Publishing, Wallingford, U.K., 2001, 486 pp.

Brant S. V. \& Gardner S.L. Phylogeny of species of the genus Litomosoides (Nematoda: Onchocercidae): evidence of rampant host switching. Journal of Parasitology, 2000, 86, 545-554.

CABAllero E. Una nueva espécie del género Litomosoides y consideraciones acerca de los caracteres sistemàticos de las espécies de este género. Anales del Instituto de Biologia, 1944, 15, 383-388.

Casiraghi M., Anderson T.J.C., Bandi C., Bazzochi C. \& GENCCHI C. A phylogenetic analysis of filarial nematodes: comparison with the phylogeny of Wolbachia endosymbionts. Parasitology, 2001, 122, 93-103.

Chitwood B.G. Some Nematodes from the caves of Yucatan. Carnegie Institution of Washington, 1938, 491, 51-66.

Diagne M., Petit G., Liot P., Cabaret J. \& Bain O. The filaria Litomosoides galizai in mites: microfilarial distribution in the host and regulation of the transmission. Annales de Parasitologie Humaine et Comparée, 1990, 65, 193-199.

Diaz-Ungria C. Nématodes nouveaux ou intéressants du Vénézuéla. Annales de Parasitologie Humaine et Comparée, $1963,38,893-914$.

Essuinger H. The genus Litomosoides Chandler, 1931 (Filarioidea: Onchocercidae) in Colombian bats and rats. Journal of Parasitology, 1973, 59, 225-246.

Gencchi C., SaCchi L., Bandi C. \& Venco L. Preliminary results on the effect of tetracycline on the embryogenesis and symbiotic bacteria (Wolbachia) of Dirofilaria immitis. An update and discussion. Parassitologia, 1998, 40, 247249.
Guerrero R., Martin C., Gardner S. L. \& Bain O. New and known species of Litomosoides (Nematoda: Filarioidea): important adult and larval characters and taxonomic changes. Comparative Parasitology, 2002, 69, 177-195.

Hoerauf A. \& Brattig N. Resistance and susceptibility in human onchocerciasis beyond Th1 vs Th2. Trends in Parasitolology, 2002, 18, 25-31.

LAWRENCE R.A. Lymphatic filariasis: what mice can tell us. Parasitology Today, 1996, 12, 267-271.

Lins DE Almeida J. Sobre um parasito de "cheiroptera": Litosomoides brasiliensis Lins de Almeida, 1936 (NematodaFilariidae). Revista do Departamento National da Produçao Animal, 1936, 3, 133-135.

Martin C., Saeftel M., Vuong P.N., Babayan S., Fischer K., Bain O. \& Hoerauf A. B-cell deficiency suppresses vaccine-induced protection against murine filariasis but does not increase the recovery rate for primary infection. Infection and Immunity, 2001, 69, 7067-7073.

Moraes Neto A.H.A, Lanfredi R.M. \& DE Souza W. Emended description of Litomosoides silvai (Nematoda: Filarioidea) of Akodon cursor (Rodentia: Muridae). Journal of Parasitology, 1996, 82, 988-991.

Notarnicola J. \& Navone G. A new species, Litomosoides odilae n. sp. (Nematoda: Onchocercidae) from Oligoryzomys nigripes (Rodentia: muridae) in the rainforest of Misiones, Argentina. Journal of Parasitology, 2002, 88, 967-971.

Notarnicola J., Bain O. \& Navone G. Two new species of Litomosoides (Nematoda: Filarioidea) in sigmodontines (Rodentia: Muridae) from Rio de la Plata marshland, Argentina. Journal of Parasitology, 2000, 86, 1318-1325.

Saint-Andre A., Blackwell N.M., Hall L.R. et al. The role of endosymbiotic Wolbachia bacteria in the pathogenesis of river blindness. Science, 2002, 295, 1892-1896.

SAUNDERS R.C. Venezuelan Macronyssidae (Acarina: Mesostigmata). Brigham Young University Science Bulletin, Biological series, 1975, vol. XX, n 2, Part 2, 75-90.

Simons N.B. A reappraisal of interfamilial relationships of bats. In: Bat biology and conservation. Kunz T.H. \& Racey P.A., eds, Smithsonian Institution Press, Washington, 1998, pp. 3-26.

Reçu le 27 janvier 2003 Accepté le 19 juin 2003 